ルム（FBP フィルム）の優れた延伸性と低レターデーショ ンが報告され, FBP の偏光板保護フィルム代替の可能性 が示された. PP シートの熱接合に関する講演では, ヒー ター形状が接着特性に及ぼす影響の報告があった。荷重/ 複屈折/光散乱を同時測定可能な二軸延伸評価機に関する 発表では，PP を例として少量サンプルによる迅速な二軸 延伸性の評価が可能なことが報告された。また，通常では 困難な高温での横延伸により得られた二軸延伸 PET フィ ルムの結晶構造解析に関する発表では, 延伸前の熱処理に
より巨大化した配向結晶が延伸応力の低下を抑制している 可能性が報告された. いずれの発表も課題はあると思われ るが, 今後の研究の進展が楽しみな内容であった.フィル ム成形に関する 5 件の講演は, 全て企業もしくは産学連携 による研究内容の発表であった。これは，製造設備が大規 模化する傾向を持つフィルム成形という分野の特徵である が, 企業研究者による実学面からの発表が多いという本学 会の特徴とも考えられる. 今後も多くの企業研究者による 発表が，本セッションで行われることを期待したい.

\title{
超臨界・発泡
}

$(\mathrm{A}-101 \sim \mathrm{A}-108)$

本セッションは大会一日目の午前に設けられ，8件の発 表が行われた. 大まかに分類すると，射出発泡成形に関す る発表が 4 件, UV 照射を利用したものが 2 件, 材料組成 に関するものが 2 件であった，各発表の概要を以下に要約 する.

射出発泡成形に関する発表では，微細発泡成形機を用い た研究が 2 件あった. 1 件は緎維強化熱可塑性プラスチッ クの射出発泡成形において, 炭素繊維プリプレグを発泡成 形品の表層にインサートすることで高い比剛性を得ようと するもので, 次世代自動車向けの軽量素材として今後の進 展が期待される。もう 1 件は CAE と気泡生成モデルを用 いて気泡径と数密度の分布を求めようとするもので, 気泡 の数密度の予測は難しいものの, 気泡サイズについては フィッティングパラメータを調整することで実験結果をよ く再現することが報告された.

射出成形のあと 2 件は発泡ガスの昇圧装置を必要としな い新規の低圧射出発泡成形に関する報告である. 注入バル

* Sugimoto, Masataka

山形大学大学院有機材料システム研究科

米沢市城南 4-3-16（勇992-8510）
杉本昌 隆*

ブと余利ガスを排出し成形を安定化するベント孔とベント 容器, 専用スクリューからなるもので, 複数の樹脂や発泡 ガスに関する成形性について報告された，低倍率であれば 片方からのガス供給でも可能とのことで, 新規成形法とし て大いに注目される。

UV 照射を用いた発表では，PCの溶媒誘起結晶化を利 用して表面に球晶を形成させ，凹凸構造を作る手法が報告 された. UV 照射とガス含浸によりマクロなクラックを抑 制しつつ微細構造を形成し, 低反射性が得られている。も う 1 件はガス含浸時の相分離構造を利用し, 多孔絶縁フィ ルムを作成する続報である。予備乾燥時間により発泡体の モルホロジーを変化させることができることや, 空隙率と 強度・比誘電率の関係が示された.

相容系ブレンドにおいて発泡倍率がブレンド比率に対し て単純な加成性が成り立たないこと, 有機系の添加剤を導 入することで発泡倍率, 気泡数密度が変化することが報告 された。

射出発泡成形に関する講演では立ち見が出るほど盛況で あった. 今後も加工技術や材料面の双方からのアプローチ により本分野の発展が期待される.

\section{マイクロ・ナノ・3 D}

$(\mathrm{F}-109 \sim \mathrm{F}-111)$

一般セッションのマイクロ・ナノ・3 D では, F-109 か ら F-111 まで 3 件の発表があった。 セッション名からは， 多くの講演発表があると予想したが, 意外とこぢんまりと したセッションになった。ただし，それぞれの講演発表は， 示唆に富んだ内容を含み, 座長としても大いに興味をそそ られた。まず F-109では, 樹脂系のレーザー粉末積層法 で多用されるポリアミド 12 (PA 12) に替えてポリブチレ ンテレフタレート (PBT) に注目し, 積層造形時の特徵 把握を目指した検討結果を報告した。実際には融点と結晶 化温度を適度に低下させた共重合 PBT の粉末を用いるこ

\footnotetext{
* Saito, Takushi

東京工業大学 工学院 機械系

東京都目黒区大岡山 2-12-1（兵152-8552）
}

\section{齊 藤 卓 志*}

とで，粉末を保持する温度を $200^{\circ} \mathrm{C}$ 未満としたレーザー積 層が可能であることを示し, 良好な条件において引張およ び曲げ強度が射出成形品の $80 \%$ 程度に至る結果を得た。 F-110では, 高速気流中に溶融樹脂を押し出すことで, 丁 度, 綿飴（コットンキャンディー）のようにポリプロピレ ンのマイクロ繊維が得られることを報告した。気流の吐出 圧力, ノズル温度が与える繊維径や性状への影響を明らか にしていたが，実際の気流速度や繊維の温度履歴に関する 情報が取得できれば，シミュレーション展開にも役立つと 考えられた. F-111では, 熱インプリントによりフィルム 表面に微細凹凸を転写した際の撥水状況を予測する新たな モデルが提示された。つまり，Cassie-Baxter モデルでは 説明できない実験結果について, 凸形状の間に侵入する液 
相の量を指標としたモデルの提案を行った. シミュレー ションによる定性傾向の一致も確認しており，より広い条 件での実験検証を経たモデルの確立が待たれる，今回，座 長を担当したセッションにおいて，各講演の内容的な共通
性は低かったものの，個々の成果は大変に興味深かったこ とから，マイクロ・ナノあるいは 3 D プリンティングが, 依然としてプラスチック成形加工において開拓すべき領域 の一つであると感じた。

\section{複合材料}

$\left(\mathrm{B}^{-}-101 \sim \mathrm{B}-112\right)$

複合材料のセッションは第 1 日目の午前と午後に行われ た. 計 12 件の発表があり，その多くで複合化による力学 特性の向上が示され，バイオマス素材を利用した複合材料 に関する発表が 5 件あった。

B-101 では，エチレンアイオノマーと層状複水酸化物 $(\mathrm{LDH})$ のナノコンポジットについて，アイオノマーと $\mathrm{LDH}$ の相互作用に関する報告がされた．イオン的相互作 用が働き, LDHの層構造の剥離が引き起こされているこ と, ナノコンポジットでは線膨張がアイオノマーと比べて 著しく抑制されていることが報告された。 B-102では，開 繊や予備含侵を必要としない成形方法として，カバーリン グ縫合糸を用いた炭素繊維強化熱可塑性プラスチック （CFRTP）の成形に関する報告がされた。成形温度，成形 時間および成形圧力を適切に設定することにより，ボイド が少なく含侵性が良くなり，従来の研究と同等の曲げ強度 を有する CFRTP が成形できることが報告された。 B-103 では，金属パウダー（SUS）と炭素繊維（CF）を $\mathrm{AS}$ 樹 脂に混練したコンパウンドの導電性に関する報告がされた SUS 単体使用時に比べ，CF を加えることで体積抵抗率が 低下することが報告された，B-104では，Wood Plastic Composite (WPC) における木粉のケミカル処理（アセチ ル化）の検討が報告された.アセチル化木粉を使用した WPC は, 成形時に焼けが発生しにくくなり, 未処理木粉 を使用した場合に比べて，濃い茶色から淡い茶色に色相が 改善された。耐候性や吸水性についてもアセチル化木粉を 使用することにより WPC の性能が改善されることが報告 された。

B-105 では，ポリプロピレン/フィラー複合材料の力学 特性に関する報告がされた。フィラーとしてガラスビーズ, 珪灰石，タルクが用いられ，タルクをコンポジットした複 合材料において最もよい引張特性が得られることが示され た。また，界面剥離による白化現象や動的粘弾性測定の結

\footnotetext{
*1 Yamanaka, Toshiyuki 東京都立産業技術研究センター 経営企画室 東京都江東区青海 2-4-10（１3135-0064）

*2 Saito, Hiromu 東京農工大学 工学府 産業技術専攻 小金井市中町 2-24-16（ 个184-8588）
}

山 中 寿 行*1 斎 藤 拓 ${ }^{* 2}$

果も報告された. B-106 では，ガラス繊維強化ポリプロピ レンコンポジットの射出成形試料の力学特性に対する射出 成形温度の影響に関する報告がされた。射出成形温度が高 いほど結晶化度が高くなり，曲げ強さや曲げ弾性率が増加 することが示された。計算で得られた母相の弾性率や繊維 にかかる締付応力の結果から力学特性の詳細が議論された. B-107 では，高充填ガラス繊維強化ポリアミドコンポジッ 卜の射出成形試料内部の繊維の配向分布を X 線 CT 3 次元的に観察された結果が報告された。繊維はスキン層で 流動方向に配向し，コア層で垂直方向に配向することが観 察され，求められた配向テンソルの分布により射出成形時 の流動が議論された，B-108では，落花生莢粉末とポリプ ロピレンのコンポジットの射出成形試料の力学特性に関す る報告がされた．落花生萊粉末の含有率の増加に伴い初期 弾性率が増加し, ベントの効果により破断伸びが増加する ことが示された。

B-109 では，ポリフェニレンサルファイドと銅の射出成 形同時接着による複合化に関する報告がされた。銅をトリ アジンチオール化合物（TES）水溶液で処理することで樹 脂と強固に接着できることが示された。 また，XPS 分析 の結果から TES 処理された銅と樹脂で S-S 結合が形成さ れ， S-S 結合により強固に接着されていることが示された. B-110 では, 植物由来ポリアミド, 植物由来ポリアミド系 熱可塑性エラストマーと麻繊維から成る 3 成分系バイオマ ス複合材料の麻繊維長が機械的性質に及ぼす影響について 報告がされた。繊維長の増加に伴い引張強度や曲げ強さは 増加するのに対して，曲げ弾性率は繊維長が $10 \mathrm{~mm}$ で最 大になることが示された，B-111では，セルロース中の水 酸基をアクリレート基に置換したバイオマス材料に対して 熱ナノインプリントすることで, 幅が $5 \mu \mathrm{m}$ の線状構造を 転写できることが報告された。このバイオマス材料は高い 酸素透過率を示し, 気泡のないナノインプリント材料が得 られることが報告された，B-112では，木粉をポリプロピ レンにコンポジットした WPC に対してナノインデンテー ション法による微視的な硬度評価の結果が報告された。吸 水や乾燥に伴う木粉の界面付近における硬度変化の結果か ら，木粉相の構造変化のモデルが提案された。 